[Note]

\title{
The First Appearance of Toxic Dinoflagellate Alexandrium tamarense (Gonyaulacales, Dinophyceae) Responsible for the PSP Contaminations in Gamak Bay, Korea
}

\author{
Hyeon Ho Shin ${ }^{1}$, Yang Ho Yoon ${ }^{2}$, Hisae Kawami ${ }^{1}$, Mitsunori Iwataki ${ }^{3}$ \\ and Kazumi Matsuoka ${ }^{3 *}$ \\ ${ }^{1}$ Graduate School of Science and Technology, Nagasaki University, 1-14 Bunkyo-machi, Nagasaki 852-8521, Japan \\ ${ }^{2}$ Faculty of Marine Technology, Chonnam National University, San 96-1, Dundeok-dong, Yeosu 550-749, Korea \\ ${ }^{3}$ Institute for East China Sea Research, Nagasaki University, 1551-7 Taira-machi, Nagasaki 851-2213, Japan
}

\begin{abstract}
In Gamak Bay, Paralytic Shellfish Poisoning (PSP) was first detected from seafoods in 2003, however the toxin source is unknown yet. In this study, we report potential PSP producers of toxic dinoflagellates, describing morphology and abundance of cysts isolated from surface sediment of Gamak Bay. The most abundant type in these cysts was characterized with ellipsoidal and transparent wall identical to Alexandrium catenella and/or A. tamarense. Germination experiment of the cysts revealed that all motile cells germinated were morphologically identified as $A$. tamarense. This result suggests that $A$. tamarense may relate to PSP contaminations in Gamak Bay. Moreover, bottom water temperature in Gamak Bay is favorable for germination of $A$. tamarense cysts. Further studies are required to carry out the PSP monitoring for preventing the risk of PSP events that may outbreak in future at Gamak Bay.
\end{abstract}

Key Words: Alexandrium tamarense, dinoflagellate cyst, Gamak Bay, germination experiment, PSP

\section{INTRODUCTION}

Paralytic Shellfish Poisoning (PSP) causes negative environmental impacts and serious economic losses for aquaculture in many areas of the world (Han et al. 1992, 1993; Hallegraeff 1993). Several toxic dinoflagellates, Alexandrium tamarense (Lebour) Balech, A. catenella (Whedon and Kofoid) Balech, A. affine (Inoue et Fukuyo) Balech, Gymnodinium catenatum Graham and Pyrodinium bahamense var. compressum (Böhm) Steidinger, Tester \& Taylor, are well known as PSP producer (Hallegraeff 1993).

In Korea, the first record of PSP incident was reported at Busan in 1986. In that case, two peoples died due to consumption of mussels, Mytilus edulis (Chang et al. 1987). Other PSP incidents including one illness and two death due to consumption of mussels were reported in 1996 at Geoje Island, where is connected with coastal waters of Busan and Jinhae Bay at the northeast side (Lee

*Corresponding author (kazu-mtk@nagasaki-u.ac.jp) et al. 1997). Han et al. (1992) reported that the causative organism of PSP in Jinhae Bay was morphologically identified to A. tamarense. Since then outbreaks of PSP in the southeast coast including Jinhae Bay and Busan have been annual events for many years (Han et al. 1992, 1993). However, PSP toxin was first detected chemically at Gamak Bay in 2003 by high performance liquid chromatography (HPLC) toxin analysis (http://www.nfrdi. re.kr). In this bay, oyster and mussel farms, and fish aquacultures have been well developed, particularly oyster production from this bay occupies around the $30 \%$ of the total production of Korea (Lee and Cho 1990). This indicates that the bay is directly exposed to potential risk of PSP outbreak in future. Nevertheless, the causative organisms for PSP have not been examined in Gamak Bay yet.

Many toxic dinoflagellates including causative organisms for PSP produce resting cysts in their life cycle, and since the produced cysts play an important role as the seed population for seasonal blooms (Anderson and Wall 1978), cyst survey in sediments provides the information on those harmful dinoflagellates and potentially 


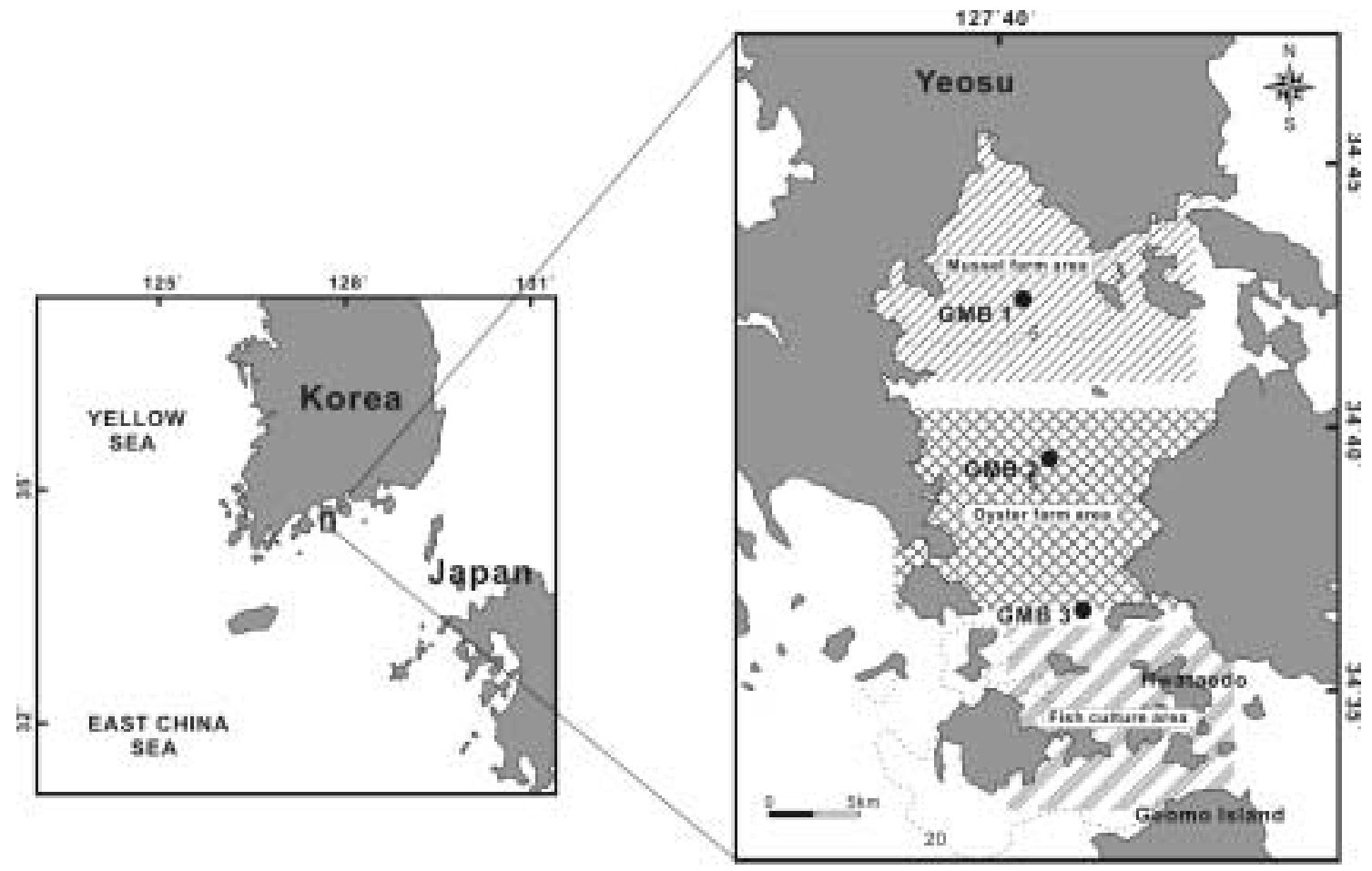

Fig. 1. Sampling stations and distribution of aquaculture ground in Gamak Bay.

risky areas of PSP outbreak. In this study, we attempted to clarify the producer of PSP toxin by detecting dinoflagellate cysts preserved in sediments, and also reported the relationship between the producer of PSP toxin and environmental conditions in Gamak Bay.

\section{MATERIALS AND METHODS}

Gamak Bay is oval in shape with $9 \mathrm{~km}$ in width and 15 $\mathrm{km}$ in length and shallow with a mean depth of about 9 $\mathrm{m}$. Many mussel and oyster farms and fish cultures are widely distributed all over the bay (Fig. 1). Surface sediments were collected at 3 stations in the bay with a gravity corer in May 2006 (Fig. 1). The top $2 \mathrm{~cm}$ of the core samples was sliced, and stored in the dark and cool conditions at $4^{\circ} \mathrm{C}$ prior to further analysis. The samples were processed with the method described by Matsuoka and Fukuyo (2000): Approximately $2 \mathrm{~g}$ of the sediment sample were placed into $100 \mathrm{ml}$ vessel, sonicated for $30 \mathrm{sec}$, and sieved through 125 and $20 \mu \mathrm{m}$ stainless steel. Cysts remaining on the $20 \mu \mathrm{m}$ mesh screen were observed under an inverted microscope (Olympus, IX 70). Also, these samples were provided for dinoflagellate cyst germination experiment.

In the germination experiment, ten ellipsoidal cysts observed in Gamak Bay (GMB3) were isolated with a micropipette and placed in a multiple well culture plates
(24 holes) containing $0.5 \mathrm{ml}$ of ESM medium (Watanabe et al. 2000). These cysts were kept in a culture chamber at $20^{\circ} \mathrm{C}$ under a constant light condition with an irradiance of $100 \mu \mathrm{mol}$ photons $\mathrm{m}^{-2} \mathrm{~s}^{-1}$, and were daily checked for the appearance of motile cell.

\section{RESULTS AND DISCUSSION}

We detected certain prominent morphology of cysts from sediments of Gamak Bay (Figs 2A-D). Of them, some cysts assumed morphologically to PSP-producing dinoflagellates, for example the cysts of spherical type (Alexandrium affine), ellipsoidal type (A. catenella/ tamarense) and G. catenatum. Among these cysts, the ellipsoidal type was the most abundant (53.2\%), followed by the spherical type and then G. catenatum cysts. Since the concentration of $G$. catenatum cyst was very low, only $0.14 \%$ of the total cyst assemblages, it is difficult that this species was causative for PSP in Gamak Bay. Ellipsoidal and transparent cysts are known to be produced by three species such as A. catenella, A. tamarense, and A. acatenella. According to Yoshida et al. (2003), these cysts do not shown morphological characteristics that enable to differentiate each other. For this reason, germination experiments were carried out for the examination of the motile cell corresponding with ellipsoidal cysts collected from Gamak Bay. 

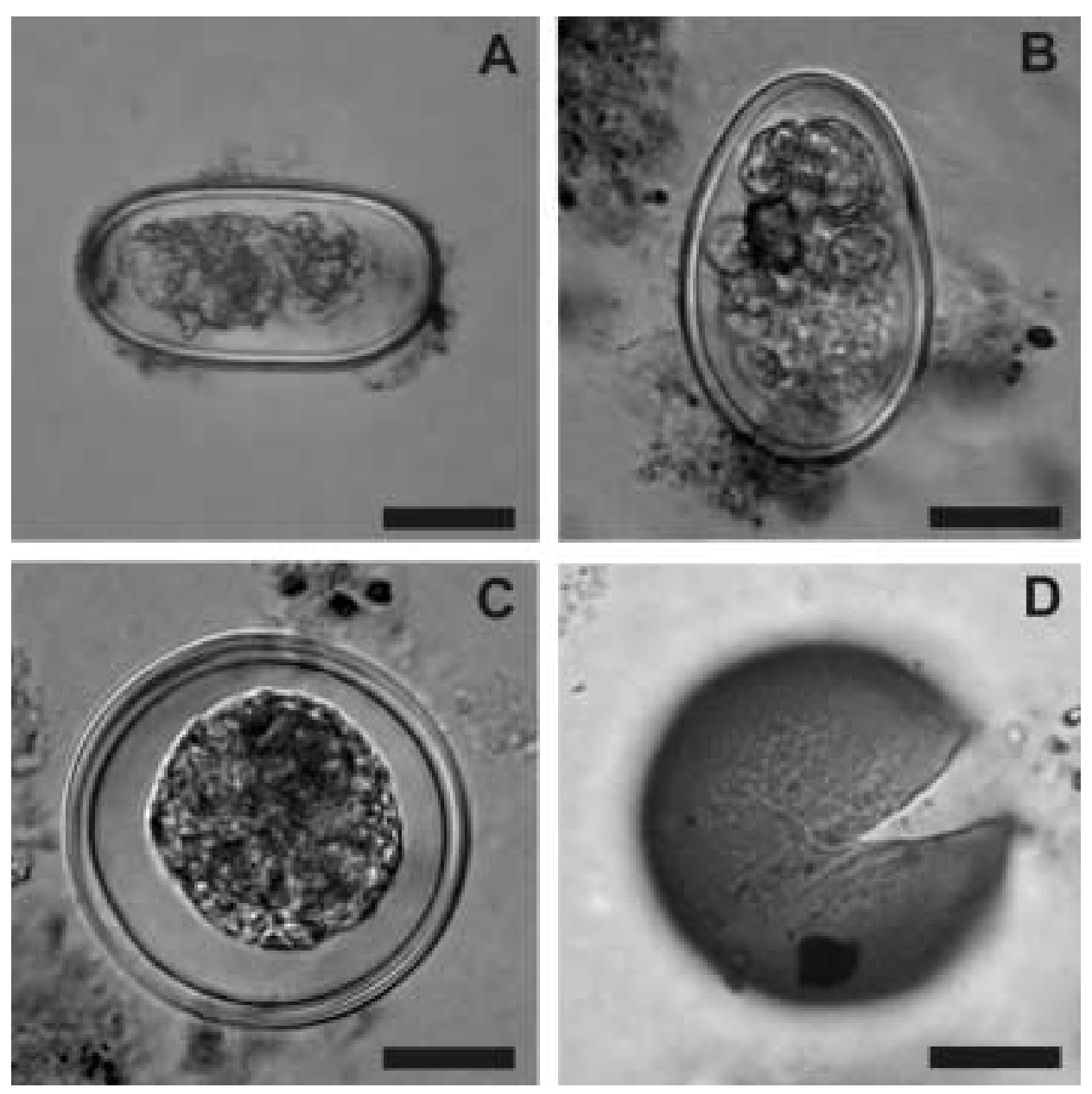

Fig. 2. Light microscopy of dinoflagellate cysts collected from surface sediments. A, B. Ellipsoidal type cysts; C. Spherical type cyst;

D. Gymnodinium catenatum cyst with brownish wall, reticulate ornaments and chasmic archeopyle. Scale bars: $10 \mu \mathrm{m}$.

Among these ellipsoidal cysts isolated in Gamak Bay, four cells were germinated (Figs 3A-F). The germinated cells were pentagonal in shape and laterally expanded. These motile forms were made up two-cells chains. The first apical plate $\left(1^{\prime}\right)$ was relatively narrow, surrounded by $2^{\prime}, 4^{\prime}, 1^{\prime \prime}$ and $6^{\prime \prime}$ plates, and directly connected with the apical pore plate (Po) (Fig. 3D). The apical pore was hook-shaped, and the ventral pore was clearly located in the $1^{\prime}$ plate, near the right side margin contacting the $4^{\prime}$ plate (Figs 3C-E). The posterior sulcal plate (SP) was large and pentagonal in shape (Fig. 3F). The posterior attachment pore was located in right side of the SP plate. All motile cells germinated from cysts incubated had the ventral pore. According to Fukuyo (1985) and Yoshida et al. (2003), the most important character differentiating $A$. tamarense from $A$. catenella is the presence of the ventral pore. In addition, $A$. tamarense in southeastern coastal waters of Korea was also identified by presence or absence of the ventral pore (Han et al. 1993; Kim et al. 2002). Therefore, the observation of the ventral pore in these species suggests that ellipsoidal type cysts accumulated in surface sediments of Gamak Bay are morphologically identical to a toxic dinoflagellate $A$. tamarense. In Korea, $A$. tamarense have frequently occurred in Jinhae Bay and adjacent areas, and offshore areas of Korea (Han et al. 1992; Han et al. 1993; Kim et al. 2002), however there was no report on species from Gamak Bay until now. Consequently, this finding might be the causative organism for PSP detected on 2003 in Gamak Bay. And, the ellipsoidal type cysts considering as A. tamarense were abundant in northern and southern area of the bay where mussel and oyster farms are developed, with average concentration of 53 cysts/g dry (Fig. 4). Such a distributional pattern seems to be controlled by a bottom topographic features as the bay is separated into two sub-basins (northern and southern basins) by a ridge developed from the east to west (Fig. 4). In addition, the cyst density was similar to those of Busan (average concentration of 41 cysts/g dry) and Geoje Island (average concentration of 79 cysts/g dry) where PSP incidents 

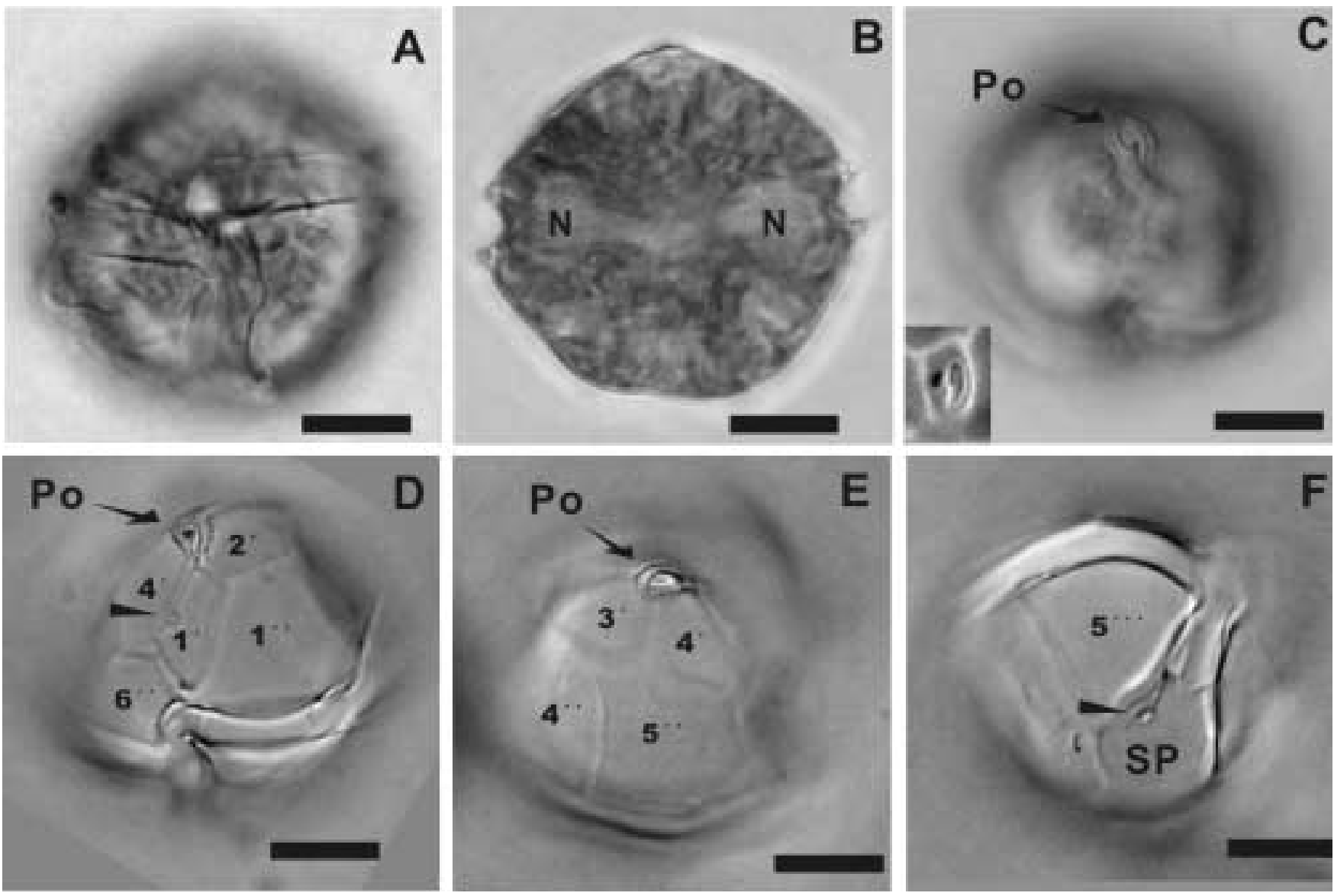

Fig. 3. Light microscopy of motile cells of Alexandrium tamarense germinated from ellipsoidal cysts. A. Surface view of the ventral side; B. Optical section in the dorso-ventral view showing the position of nucleus $(\mathrm{N})$; C. Apical view showing the apical pore plate (Po); D. Ventral view showing thecal plates with the apical pore plate (Po), the apical plate series $\left(1^{\prime}, 2^{\prime}, 4^{\prime}\right)$, and precingular plates $\left(1^{\prime \prime}, 6^{\prime \prime}\right)$. Note the ventral pore (arrowhead) located near the suture of the $1^{\prime}$ plate bordering the $4^{\prime}$ plate; E. Oblique apical view from the right side of the epitheca, showing the apical pore plate (Po), apical plates $\left(3^{\prime}, 4^{\prime}\right)$ and precingular plates (4", $\left.5^{\prime \prime}\right)$; F. Antapical view showing the $5^{\prime \prime \prime}$, the posterior sulcal plate (SP), and the posterior attachment pore (arrowhead). Scale bars: $10 \mu \mathrm{m}$.

were reported (Kim et al. 2005; Shin et al. 2007).

Kim et al. (2002) reported that germination maxima of A. tamarense cysts in Jinhae Bay were observed during the period of decreasing water temperature in December and November, and germinated motile cells may initiate the spring bloom. According to Anderson (1980), water temperature is most important environmental factor for germination of $A$. tamarense cysts, and the permissive water temperature window for germination of $A$. tamarense cysts ranges from 5 to $21^{\circ} \mathrm{C}$ (Anderson 1998). Bottom water temperature at Gamak Bay ranges from 5.9 to $23.9^{\circ} \mathrm{C}$, and that in November was similar to that of Jinhae Bay (Fig. 5). This result suggests that germination of A tamarense cysts at Gamak Bay may be possible throughout the year except in August when water temperature are above $21^{\circ} \mathrm{C}$, and the environmental condition for germination of $A$. tamarense cysts is as favorable as that of Jinhae Bay. In addition, as shellfish industries in Gamak Bay are also developed well, this bay is certainly exposed to potential risk of PSP caused by $A$. tamarense. Therefore, further studies are required to carry out the PSP monitoring for preventing the risk of PSP events that may outbreak in future at Gamak Bay.

\section{ACKNOWLEDGEMENTS}

We thank D.Y. Kim and Y.K. Park of Chonnam National University, Korea for their help during the field survey. This work was partly supported by Grant-in-Aid for Science of Japan Society for the Promotion of Science (Re: 18340166). 


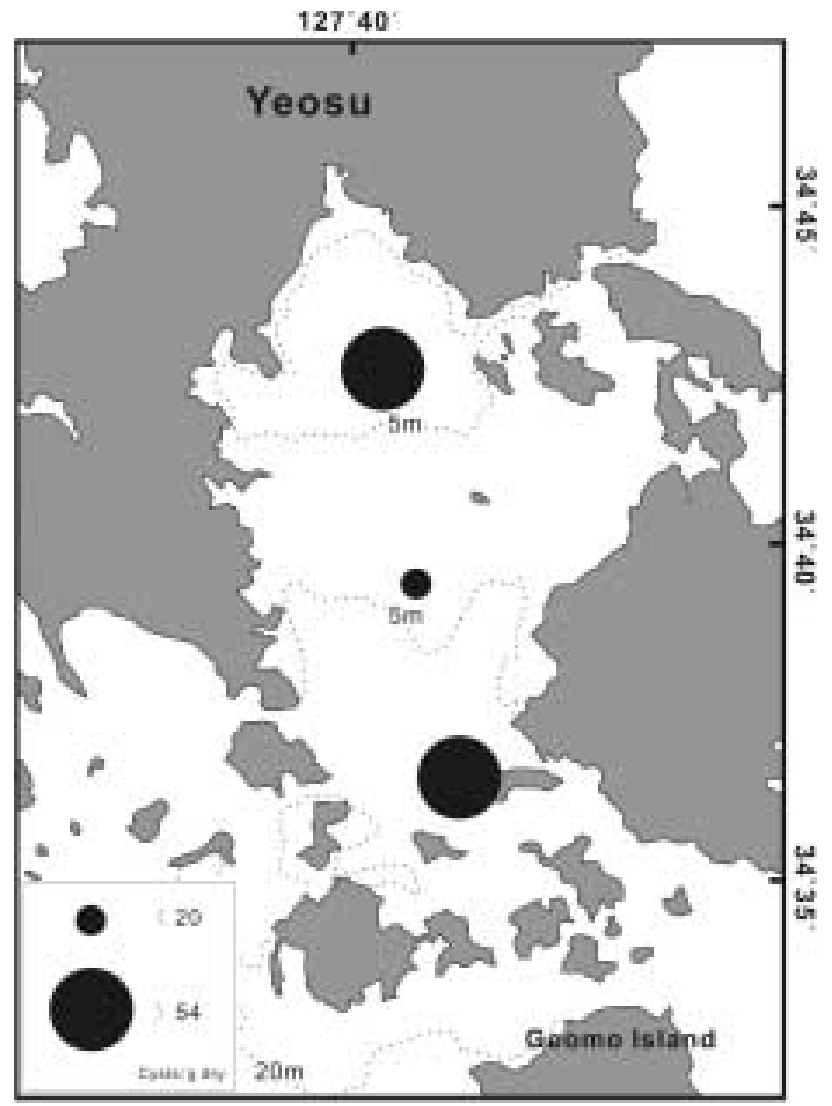

Fig. 4. Distribution of ellipsoidal type cysts in Gamak Bay.

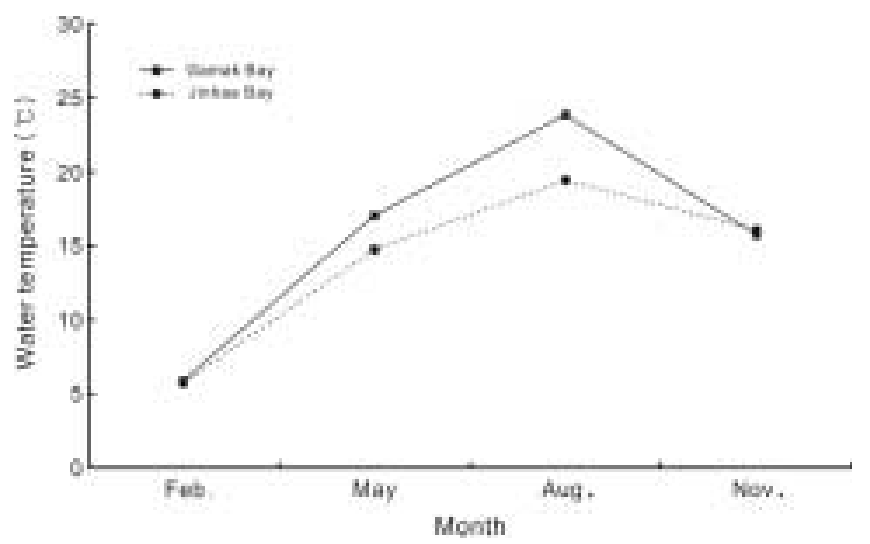

Fig. 5. Seasonal variations of average bottom water temperature from 2002 to 2005 at Gamak Bay and Jinhae Bay (data from http://www.nfrdi.re.kr).

\section{REFERENCES}

Anderson D.M. 1980. Effects of temperature conditioning on development and germination of Gonyaulax tamarensis (Dinophyceae) hypnozygotes. J. Phycol. 16: 166-172.

Anderson D.M. 1998. Physiology and bloom dynamics of toxic Alexandrium species, with emphasis on life cycle transition. In: Anderson D.M., Cembella A.D. and Hallegraeff G.M. (eds), Physiological ecology of harmful algal blooms. Springer-
Verlag, Berlin. pp. 29-48.

Anderson D.M. and Wall D. 1978. Potential importance of benthic cysts of Gonyaulax tamarensis and G. excavata in initiating toxic dinoflagellate blooms. J. Phycol. 14: 224-234.

Chang D.S., Shin I.S., Pyeun J.H. and Park Y.H. 1987. A study on paralytic shellfish poison of sea mussel Mytilus edulis. Bull. Korean Fish. Soc. 20: 293-299. (in Korean)

Fukuyo Y. 1985. Morphology of Protogonyaulax tamarensis (Lebour) Taylor and Protogonyaulax catenella (Whedon and Kofoid) Taylor from Japanese coastal waters. Bull. Mar. Sci. 37: 529-537.

Hallegraeff G.M. 1993. A review of harmful algal blooms and their apparent global increase. Phycologia 32: 79-99.

Han M.S., Jeon J.K. and Kim Y.O. 1992. Occurrence of dinoflagellate Alexandrium tamarense, a causative organism of paralytic shellfish poisoning in Chinhae Bay, Korea. J. Plankton Res. 14: 1581-1592.

Han M.S., Jeon J.K. and Yoon Y.H. 1993. Distribution and toxic profiles of Alexandrium tamarense (Lebour) Balech (Dinoflagellate) in the Southeastern coastal waters, Korea. Korean J. Phycol. 8: 7-13.

Kim H.J., Moon C.H. and Cho H.J. 2005. Spacial-temporal characteristics of dinoflagellate cyst distribution in sediments of Busan Harbor. J. Korean Soc. Oceanogr. 10: 196-203. (in Korean)

Kim K.Y., Yoshida M., Fukuyo Y. and Kim C.H. 2002. Morphological observation of Alexandrium tamarense (Lebour) Balech, A. catenella (Whedon et Kofoid) Balech and one related morphotype (Dinophyceae) in Korea. Algae 17: 11-19.

Kim Y.O., Park M.H. and Han M.S. 2002. Role of cyst germination in the bloom initiation of Alexandrium tamarense (Dinophyceae) in Masan Bay, Korea. Aquat. Microb. Ecol. 29: 279-286.

Lee J.S., Shin I.S., Kim Y.M. and Chang D.S. 1997. Paralytic shellfish toxins in the mussel, Mytilus edulis, caused the shellfish poisoning accident at Geoje, Korea, in 1996. J. Korean Fish. Soc. 30: 158-160. (in Korean)

Lee K.H. and Cho K.D. 1990. Distribution of the temperature and salinity in Kamak Bay. Bull. Korean Fish. Soc. 23: 25-39. (in Korean with English abstract)

Matsuoka K. and Fukuyo Y. 2000. Technical guide for modern dinoflagellate cyst study. WESTPAC-HAB/WESTPAC/ IOC, University of Tokyo, Tokyo, $29 \mathrm{pp}$.

Shin H.H., Yoon Y.H. and Matsuoka K. 2007. Modern dinoflagellate cysts distribution off the eastern part of Geoje Island. Ocean Sci. J. 42: 31-39.

Watanabe M., Kawachi M., Hiroki M. and Kasai F. 2000. NIEScollection: List of strains, ed. 6. Microalgae and protozoa. National Institute of Environmental Studies, Tsukuba, Japan. 159 pp.

Yoshida M., Mizushima K. and Matsuoka K. 2003. Alexandrium acatenella (Gonyaulacales: Dinophyceae): Morphological characteristics of vegetative cell and resting cyst. Plankton Biol. Ecol. 50: 61-64.

Received 22 August 2008

Accepted 11 October 2008 
